\title{
Potential diagnostic value of IncRNA SPRY4-IT1 in hepatocellular carcinoma
}

\author{
WEI JING, SHANSHAN GAO, MAN ZHU, PING LUO, XUAN JING, HONGYAN CHAI and JIANCHENG TU \\ Department of Clinical Laboratory Medicine and Center for Gene Diagnosis, Zhongnan Hospital of Wuhan University, \\ Wuhan, Hubei 430071, P.R. China
}

Received January 26, 2016; Accepted March 4, 2016

DOI: $10.3892 /$ or.2016.4859

\begin{abstract}
The manifestation of hepatocellular carcinoma (HCC) involves a multi-factor, multi-step and complex process. Due to the lack of early prediction indices, numerous patients are diagnosed in their late stage. Recently, research in the field of non-coding RNAs (ncRNAs) has changed the original idea that ncRNA genes are just 'noise'. Cumulative evidence shows that long non-coding RNAs (lncRNAs) among ncRNAs play an increasingly important role in epigenetics, pre-transcription and post-transcription. In the present study, we focused on the expression pattern of lncRNA SPRY4 intronic transcript 1 (SPRY4-IT1) and its clinical significance in HCC diagnostics. We analyzed the expression, its association with clinical characteristics and the diagnostic value of SPRY4-IT1 using HCC tissues, cell lines and plasma. The levels of SPRY4-IT1 were upregulated in HCC and were associated with tumor differentiation $(r=0.249, p=0.039)$, tumor size $(r=0.258, p=0.024)$ and tumor-node-metastasis (TNM) stage $(\mathrm{r}=0.287, \mathrm{p}=0.015)$. Meanwhile, the sensitive of SPRY4-IT1 was $87.3 \%$ in differentiating HCC patients from controls. Our data suggest that SPRY4-IT1 plays a critical role in HCC tumorigenesis and may be considered as a potential diagnostic indicator in HCC.
\end{abstract}

\section{Introduction}

Hepatocellular carcinoma (HCC) is the fifth most common cancer among males, and it is the ninth leading cause of cancerrelated deaths in females worldwide (1). HCC is the most common form of liver cancer, accounting for between 85 and $90 \%$ of all primary liver cancers (2). The leading risk factor for developing HCC is cirrhosis and the rate is $80-90 \%$ (3). It has been reported that chronic hepatitis $\mathrm{B}$ virus (HBV) infection is

Correspondence to: Professor Jiancheng Tu, Department of Clinical Laboratory Medicine and Center for Gene Diagnosis, Zhongnan Hospital of Wuhan University, 169 Donghu Road, Hubei 430071, P.R. China

E-mail: jianchengtu@whu.edu.cn

Key words: long non-coding RNA, SPRY4-IT1, HCC, tumorigenesis diagnosis the cause of the majority of cirrhosis cases (4). Despite the fact that patients can be successfully treated by surgery, liver transplantation, chemotherapy and interventional therapy $(5,6)$, HCC is commonly diagnosed in the advanced stage after related symptoms appear, and the 5-year survival rate remains at $7 \%$ (7). During the past 20 years, the mortality rate associated with HCC has significantly increased and epidemiologic evidence indicates that the burden on medical care costs may significantly increase during the next decades (8). The serum $\alpha$-fetoprotein (AFP) level is used as a diagnostic marker for $\mathrm{HCC}$, yet AFP results may be negative in as many as $40 \%$ of cases presenting with early stage HCC. Even in $15-30 \%$ of advanced patients, AFP levels remain normal and imaging examination must be utilized to discriminate between tumor and non-neoplastic lesions (9). The lack of knowledge regarding the mechanisms of the tumorigenesis of HCC results in ineffective therapy and a high probability of relapse after treatment (10). Therefore, identification of reliable diagnostic markers for HCC is urgently needed.

Long non-coding RNAs (lncRNAs), which were first described by Brockdorff et al in 1992 (11), are molecules with a length longer than $200 \mathrm{bp}$ that cannot code protein products. Khachane and Harrison (12) demonstrated that the proportion of lncRNAs associated with cancer was 2-fold higher than that of protein coding genes in the human genome. Increasing evidence has pointed to a relationship between lncRNAs and cancers, including metastasis, migration, apoptosis and clinical outcome (13). For example, highly upregulated in liver cancer (HULC) is a specific gene which is markedly upregulated both in tissue and plasma in HCC (5). The H19 lncRNA was found to be associated with tumorigenesis and invasion, partially via the regulation of carcinogenic miRNA-675 which locates in its first exon (14). IncRNA-ROR can downregulate miR-145, causing cancer progression and drug resistance (15). Urothelial carcinoma-associated 1 (UCA1) can directly bind to miR-216b, and the abnormal expression of UCA1 in HCC is correlated with tumor-node-metastasis (TNM) stage, metastasis, survival and AFP level (16). Unfortunately, the functional role of lncRNAs in HCC remains largely unexplored.

lncRNA SPRY4 intronic transcript 1 (SPRY4-IT1) is a 703-bp molecule which maps to chromosome 5q31.3. This transcript may mediate cell growth, proliferation, apoptosis and was found to be upregulated in several different tumors, including glioma, prostate, breast, non-small cell lung and 
esophageal squamous cell cancer (17-21). Mazar et al (22) found that SPRY4-IT1 was upregulated in melanoma cells, and demonstrated that RNAi-mediated knockdown of SPRY4-IT1 may induce apoptosis via lipin 2-mediated alterations in lipid metabolism leading to cellular lipotoxicity. Peng et al (23) indicated that upregulation of SPRY4-IT1 expression was significantly correlated with tumor size, depth of invasion, distant metastasis and TNM stage in gastric cancer, and knockdown of SPRY4-IT1 expression suppressed cell migration, invasion, proliferation and colony formation capabilities. Zhang et al (24) showed that overexpression of SPRY4-IT1 was associated with the progression and development of clear cell renal carcinoma. Much research concerning SPRY4-IT1 in cancers has been carried out. However, the clinical and prognostic significance of IncRNA SPRY4-IT1 expression in HCC has not been reported.

The aim of the present study was to investigate the gene expression of lncRNA SPRY4-IT1 in HCC patients and cell lines, and then analyze the correlation between clinical characteristics and SPRY4-IT1 levels. We also evaluated the diagnostic value of SPRY4-IT1 in plasma. Moreover, we assessed whether SPRY4-IT1 could serve as a new biomarker for HCC.

\section{Materials and methods}

Tissue and blood samples. We recruited 87 patients $(81$ men

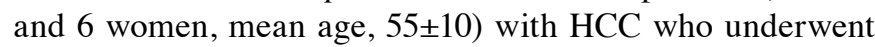
surgery without preoperative chemotherapy or radiotherapy from 2011 to 2015 at Zhongnan Hospital of Wuhan University, Wuhan, China. Tumor tissue specimens and corresponding adjacent non-tumor tissues were collected and stored at $-80^{\circ} \mathrm{C}$ until use.

Whole blood samples of 145 patients were obtained from Zhongnan Hospital of Wuhan University during 2015. The samples were classified into three groups: pre-operation (48 men and 12 women; mean age, $57 \pm 12$ ), 2 weeks after surgery (48 men and 12 women; mean age, $57 \pm 12$ ), patients with hepatitis B and cirrhosis (63 men and 22 women; mean age, $54 \pm 12$ ), which were collected in EDTA tubes and centrifuged at 2,000 $\mathrm{xg}$ for $5 \mathrm{~min}$ at $4^{\circ} \mathrm{C}$ to spin down the blood cells. The supernatants were transferred to microcentrifuge tubes and centrifuged at $12,000 \mathrm{xg}$ for $5 \mathrm{~min}$ at $4^{\circ} \mathrm{C}$. The plasma was then stored at $-80^{\circ} \mathrm{C}$ until use. Patients who underwent previous preoperative chemotherapy or radiotherapy were excluded from the study. Then, from the Physical Examination Center, we collected 63 controls (50 men and 13 women; mean age, $54 \pm 11$ ), who were without hepatitis, hepatic diseases and abnormal liver biochemical outcomes.

Ethical approval. Tissue and plasma specimens were collected after obtaining informed consent of the patients in accordance with the institutional ethical guidelines and approved by the Ethics Committee of Zhongnan Hospital of Wuhan University (Wuhan, China) for the use of these clinical materials.

Cell culture. The human HCC Hep-3B and HepG2 cell lines were obtained from the China Center for Type Culture Collection (CCTCC; Wuhan, China). HuH-7 and the normal human hepatocyte cell line L-02 were purchased from the
Procell Inc. (Wuhan, China). MHCC97-L and HCCLM-9 cells were maintained at our laboratory. MHCC97-L cells were cultured in Dulbecco's modified Eagle's medium (DMEM), and the other cell lines were cultured in RPMI-1640 medium (both from Gibco, Grand Island, NY, USA). All cells were cultured at $37^{\circ} \mathrm{C}$ in $5 \% \mathrm{CO}_{2}$ in culture media containing $10 \%$ fetal bovine serum (FBS; Gibco).

RNA extraction. Total RNA was extracted from tissues and cells using TRIzol reagent (Invitrogen, Carlsbad, CA, USA), and we used total RNA separate extraction kit (BioTeke, Beijing, China) for plasma samples. RNA was reverse transcribed to cDNA using PrimeScript ${ }^{\mathrm{TM}}$ RT reagent kit with gDNA Eraser (Takara, Japan). The conditions were as follows: $42^{\circ} \mathrm{C}$ for $2 \mathrm{~min}$, and then $37^{\circ} \mathrm{C}$ for $15 \mathrm{~min}$, and $85^{\circ} \mathrm{C}$ for $5 \mathrm{sec}$.

Real-time PCR analysis. The expression of SPRY4-IT1 was determined on the Bio-Rad CFX96 (Bio-Rad Laboratories, Inc., Hercules, CA, USA) using SYBR-Green I Premix Ex Taq according to the manufacturer's instructions. The reactions started at $95^{\circ} \mathrm{C}$ for $5 \mathrm{~min}$, followed by 45 cycles of $95^{\circ} \mathrm{C}$ for $30 \mathrm{sec}, 61^{\circ} \mathrm{C}$ for $30 \mathrm{sec}$ and $72^{\circ} \mathrm{C}$ for $30 \mathrm{sec}$. In order to normalize the results for the qPCR, expression of $18 \mathrm{~s}$ was used. The synthesized primers were as follows: SPRY4-IT1 sense, 5'-GTTTTTGCTGAGCTGGTGGTT-3' and antisense, 5'-ATGGCTCCACTGGGCATATT-3'; 18s sense, 5'-CAGCC ACCCGAGATTGAGCA-3' and antisense, 5'-TAGTAGCGAC GGGCGGTGTG-3'. The relative gene expression level was calculated using the comparative $\mathrm{Ct}$ method formula $2^{-\Delta \mathrm{Ct}}$. All experiments were carried out in duplicate and each data point represents the mean results of the duplicate experiments.

Statistical analysis. All statistical analyses were carried out using SPSS version 17.0 (SPSS, Inc., Chicago, IL, USA) and GraphPad Prism 5.0 (GraphPad Software, La Jolla, CA, USA). The data in the present study were presented as mean \pm standard deviation (SD) or median (25 and 75 percentiles). $\mathrm{p}<0.05$ was considered to indicate a statistically significant result. The Shapiro-Wilk test was carried out to check the normality of the distribution. The normally distributed numeric variables were evaluated by Student's t-test, while non-normally distributed variables were analyzed by Kruskal-Wallis variance analysis. One-way ANOVA was used to validate the different expression levels of SPRY4-IT1 among subgroups. Chi-square test was used to analyze the categorical variables. To estimate the diagnostic value of the biomarkers, area under the corresponding ROC curve analysis was performed. Finally, correlations were analyzed using Pearson correlation.

\section{Results}

SPRY4-IT1 expression is upregulated in HCC tissues and cell lines. The relative expression levels of SPRY4-IT1 were assessed by RT-qPCR. In 87 HCC and adjacent normal liver tissues, the SPRY4-IT1 level in the tumor tissues was significantly upregulated when compared to the level in the non-tumor tissues (p<0.01; Fig. 1A). Expression of SPRY4-IT1 relative to $18 \mathrm{~s}$ in HCC cell lines was compared with a normal human hepatocyte cell line. The results showed that the expression of SPRY4-IT1 was much higher in the HCC cell 
Table I. Association of SPRY4-IT1 expression with clinical parameters in $\mathrm{HCC}$.

\begin{tabular}{|c|c|c|c|c|}
\hline \multirow[b]{2}{*}{ Characteristics } & \multirow[b]{2}{*}{$\mathrm{n}$} & \multicolumn{3}{|c|}{$\begin{array}{l}\text { SPRY4-IT1 relative } \\
\text { expression }(-\log )\end{array}$} \\
\hline & & Mean $\pm \mathrm{SD}$ & $\mathrm{t}$ & P-value \\
\hline Tissue & & & -3.060 & $0.003^{\mathrm{b}}$ \\
\hline $\mathrm{HCC}$ & 87 & $5.92 \pm 0.93$ & & \\
\hline $\begin{array}{l}\text { Adjacent non- } \\
\text { cancerous liver }\end{array}$ & 87 & $6.19 \pm 0.80$ & & \\
\hline Gender & & & 0.394 & 0.694 \\
\hline Male & 81 & $5.93 \pm 0.89$ & & \\
\hline Female & 6 & $5.78 \pm 1.39$ & & \\
\hline Age (years) & & & -0.509 & 0.612 \\
\hline$<55$ & 40 & $5.87 \pm 0.96$ & & \\
\hline$\geq 55$ & 47 & $5.97 \pm 0.90$ & & \\
\hline Smoking status & & & 0.488 & 0.627 \\
\hline Negative & 52 & $5.96 \pm 0.89$ & & \\
\hline Positive & 35 & $5.86 \pm 0.99$ & & \\
\hline Alcoholism & & & 1.569 & 0.122 \\
\hline Negative & 70 & $6.00 \pm 0.94$ & & \\
\hline Positive & 17 & $5.61 \pm 0.81$ & & \\
\hline Differentiation & & & 2.106 & $0.039^{\mathrm{a}}$ \\
\hline High & 10 & $6.51 \pm 0.97$ & & \\
\hline Moderate/low & 59 & $5.89 \pm 0.86$ & & \\
\hline Tumor size $(\mathrm{cm})$ & & & 2.298 & 0.024 \\
\hline$<10$ & 55 & $6.13 \pm 0.95$ & & \\
\hline$\geq 10$ & 21 & $5.61 \pm 0.59$ & & \\
\hline Tumor nodes & & & 0.678 & 0.500 \\
\hline Single & 66 & $5.97 \pm 0.99$ & & \\
\hline Multi & 10 & $5.77 \pm 0.66$ & & \\
\hline TNM stage & & & 2.514 & $0.015^{\mathrm{a}}$ \\
\hline I-II & 35 & $6.26 \pm 1.00$ & & \\
\hline III-IV & 41 & $5.75 \pm 0.73$ & & \\
\hline HBV DNA (IU/ml) & & & 1.490 & 0.147 \\
\hline$<500$ & 11 & $6.12 \pm 0.78$ & & \\
\hline$\geq 500$ & 21 & $5.69 \pm 0.78$ & & \\
\hline Cirrhosis & & & -1.129 & 0.262 \\
\hline Negative & 39 & $5.80 \pm 0.85$ & & \\
\hline Positive & 48 & $6.02 \pm 0.98$ & & \\
\hline $\mathrm{AFP}(\mathrm{ng} / \mathrm{ml})$ & & & 0.085 & 0.932 \\
\hline$<200$ & 38 & $5.98 \pm 0.88$ & & \\
\hline$\geq 200$ & 31 & $5.96 \pm 0.95$ & & \\
\hline $\mathrm{CEA}(\mu \mathrm{g} / \mathrm{l})$ & & & 0.471 & 0.640 \\
\hline$<7.2$ & 44 & $5.94 \pm 0.79$ & & \\
\hline$\geq 7.2$ & 3 & $5.72 \pm 0.71$ & & \\
\hline ALT (U/l) & & & -0.385 & 0.701 \\
\hline$<46$ & 49 & $5.89 \pm 0.85$ & & \\
\hline$\geq 46$ & 38 & $5.97 \pm 1.00$ & & \\
\hline AST (U/l) & & & 0.676 & 0.501 \\
\hline$<46$ & 45 & $5.99 \pm 0.87$ & & \\
\hline$\geq 46$ & 42 & $5.85 \pm 1.00$ & & \\
\hline
\end{tabular}

Table I. Continued

\begin{tabular}{|c|c|c|c|c|}
\hline \multirow[b]{2}{*}{ Characteristics } & \multirow[b]{2}{*}{$\mathrm{n}$} & \multicolumn{3}{|c|}{$\begin{array}{l}\text { SPRY4-IT1 relative } \\
\text { expression }(-\log )\end{array}$} \\
\hline & & Mean \pm SD & $\mathrm{t}$ & P-value \\
\hline GGT (U/l) & & & 0.967 & 0.337 \\
\hline$<55$ & 34 & $6.03 \pm 0.85$ & & \\
\hline$\geq 55$ & 44 & $5.83 \pm 0.94$ & & \\
\hline 5'-NT (U/1) & & & 0.482 & 0.631 \\
\hline$<10$ & 61 & $5.87 \pm 0.90$ & & \\
\hline$\geq 10$ & 2 & $5.56 \pm 0.81$ & & \\
\hline GLU (mmol/l) & & & -0.054 & 0.957 \\
\hline$<6.2$ & 64 & $5.84 \pm 0.85$ & & \\
\hline$\geq 6.2$ & 23 & $5.86 \pm 0.68$ & & \\
\hline
\end{tabular}

Data are expressed as the mean \pm SD. ${ }^{\mathrm{a}} \mathrm{p}<0.05,{ }^{\mathrm{b}} \mathrm{p}<0.01$. HCC , hepatocellular carcinoma; SPRY4-IT1, SPRY4 intronic transcript 1; TNM, tumor-node-metastasis; HBV, hepatitis B virus; AFP, $\alpha$-fetoprotein; CEA, carcinoembryonic antigen; ALT, alanine aminotransferase; AST, aspartate aminotransferase; GGT, $\gamma$-glutamyl transferase; 5'-NT, 5'-nucleotidase; GLU, glucose.
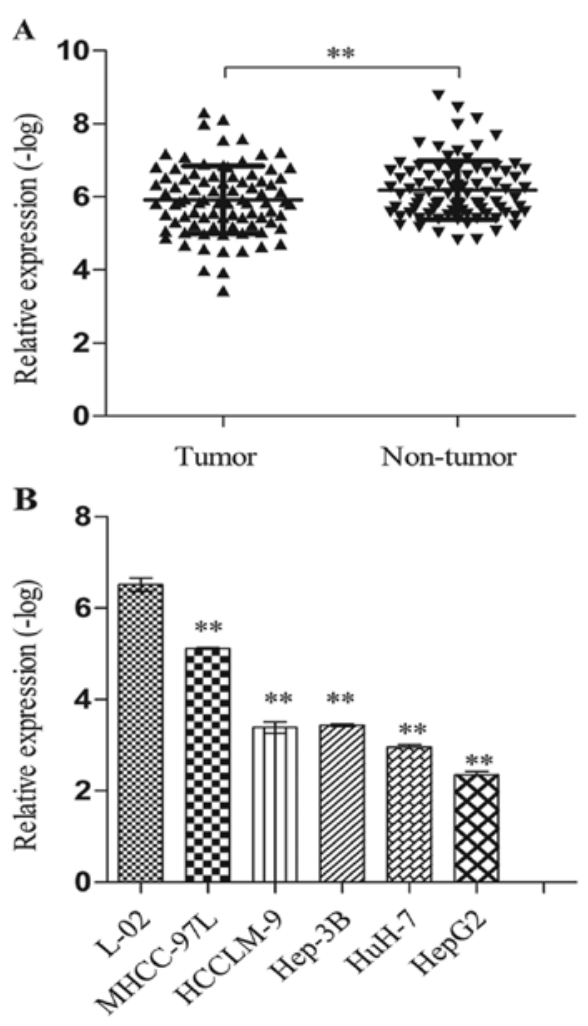

Figure 1. SPRY4-IT1 expression in HCC tissues and cell lines. The relative SPRY4-IT1 expression was determined using RT-qPCR. (A) SPRY4-IT1 levels in the tumor tissues were significantly higher than these levels in the non-tumor tissues. (B) The expression of SPRY4-IT1 was much higher in HCC cell lines than its expression in L- 02 cells. Results are expressed as mean \pm SD. All data were analyzed using Student's t-test. ${ }^{*} \mathrm{p}<0.05,{ }^{* *} \mathrm{p}<0.01$.

lines than that in the L-02 cells (MHCC97-L vs. L-02, $\mathrm{p}<0.01$; HCCLM-9 vs. L-02, p<0.01; Hep-3B vs. L-02, p<0.01; HuH-7 vs. L-02, p<0.01; HepG2 vs. L-02, p<0.01; Fig. 1B). 
Table II. Correlation analysis of SPRY4-IT1 in relation to clinical parameters of the HCC cases.

\begin{tabular}{lc} 
Characteristics & Correlation coefficient \\
\hline $\begin{array}{l}\text { Differentiation } \\
\text { (high vs. moderate/low) }\end{array}$ & 0.249 \\
Size $(<10$ vs. $\geq 10)$ & 0.258 \\
TNM stage (I-II vs. III-IV) & 0.287 \\
\hline
\end{tabular}

SPRY4-IT1, SPRY4 intronic transcript 1; TNM, tumor-node-metastasis.

Correlation between SPRY4-IT1 and clinical variables. We detected the correlation between SPRY4-IT1 and clinical parameters. As shown in Tables I and II, the level of SPRY4-IT1 expression was significantly correlated with differentiation $(\mathrm{r}=0.249, \mathrm{p}=0.039)$, tumor size $(\mathrm{r}=0.258, \mathrm{p}=0.024)$ and TNM stage $(r=0.287, p=0.015)$ (Fig. 2). However, no correlations were found in regard to gender, age, smoking, alcoholism, cirrhosis, AFP, HBV-DNA and other biochemical indices.

SPRY4-IT1 levels in plasma among subgroups. The main demographic and clinical characteristics of the studied subjects were illustrated in Table III. No difference was observed in regard to important risk factors including gender, age, smoking, alcoholism and glucose (GLU) in the three groups. There was a significant difference in alanine aminotransferase (ALT),

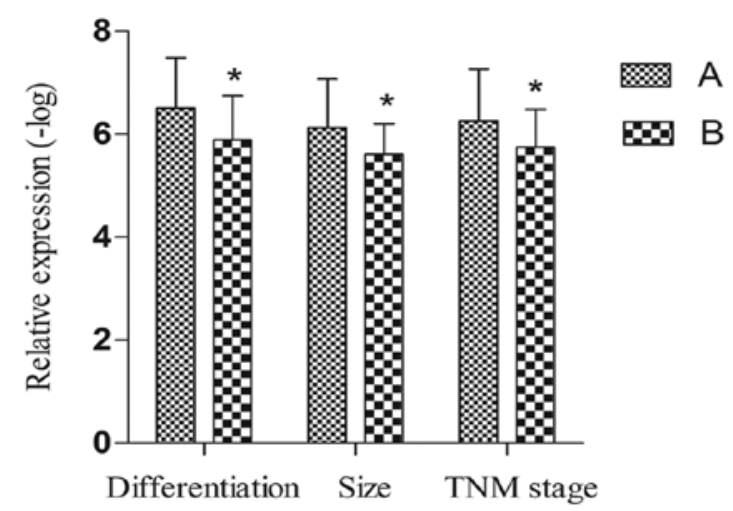

Figure 2. Association of SPRY4-IT1 expression with clinical parameters in HCC. Differentiation: A, high; B, moderate/low; size: A, $<10 \mathrm{~cm}$; B, $\geq 10 \mathrm{~cm}$; TNM stage: A, I-II; B, III-IV. Results are expressed as mean \pm SD. All data were analyzed using Student's t-test. " $\mathrm{p}<0.05$.

aspartate aminotransferase (AST), total bilirubin (TBIL) and $\gamma$-glutamyl transferase (GGT) among the groups.

To observe the value of SPRY4-IT1 as a biomarker, the levels of plasma target lncRNA in 60 HCC patients, 85 hepatitis B and cirrhosis patients, and 63 control cases were measured by RT-qPCR. The present study showed that the expression of SPRY4-IT1 at pre-operation was higher than that at postoperation, in hepatitis B and cirrhosis and the control groups (pre-operation vs. post-operation: $\mathrm{p}<0.01$; pre-operation vs. hepatitis $B$ and cirrhosis: $p<0.05$; pre-operation vs. the controls: $\mathrm{p}<0.001)$ (Fig. 3A). There were 60 paired plasma samples in

Table III. Characteristics of the studied subjects.

\begin{tabular}{|c|c|c|c|c|}
\hline Characteristics & $\begin{array}{l}\text { Pre-operation } \\
\quad \mathrm{n}=60\end{array}$ & $\begin{array}{l}\text { Hepatitis B and cirrhosis } \\
\qquad \mathrm{n}=85\end{array}$ & $\begin{array}{c}\text { Control } \\
\mathrm{n}=63\end{array}$ & P-value \\
\hline Gender & & & & $0.639^{\mathrm{a}}$ \\
\hline Male & 48 & 63 & 50 & \\
\hline Female & 12 & 22 & 13 & \\
\hline Age (years) & & & & $0.424^{\mathrm{a}}$ \\
\hline$<55$ & 14 & 28 & 20 & \\
\hline$\geq 55$ & 46 & 57 & 43 & \\
\hline Smoking & & & & $0.826^{\mathrm{a}}$ \\
\hline Negative & 33 & 50 & 38 & \\
\hline Positive & 27 & 35 & 25 & \\
\hline Alcoholism & & & & $0.322^{\mathrm{a}}$ \\
\hline Negative & 42 & 55 & 48 & \\
\hline Positive & 18 & 30 & 15 & \\
\hline $\operatorname{ALT}(\mathrm{U} / \mathrm{l})$ & $44(27,88)^{\mathrm{c}}$ & $42(24,100)^{\mathrm{c}}$ & $20(16,27)^{\mathrm{c}}$ & $<0.001^{\mathrm{b}}$ \\
\hline $\operatorname{AST}(\mathrm{U} / \mathrm{l})$ & $55(30,104)^{\mathrm{c}}$ & $46(30,102)^{\mathrm{c}}$ & $22(20,26)^{\mathrm{c}}$ & $<0.001^{\mathrm{b}}$ \\
\hline TBIL $(\mu \mathrm{mol} / \mathrm{l})$ & $23(16,39)^{\mathrm{c}}$ & $27(16,72)^{\mathrm{c}}$ & $19(15,21)^{\mathrm{c}}$ & $<0.001^{\mathrm{b}}$ \\
\hline GGT (U/l) & $78(42,204)^{\mathrm{c}}$ & $59(29,98)^{\mathrm{c}}$ & $17(14,24)^{\mathrm{c}}$ & $<0.001^{\mathrm{b}}$ \\
\hline GLU (mmol/l) & $4.9(4.6,5.8)^{\mathrm{c}}$ & $5.1(4.4,5.7)^{\mathrm{c}}$ & $4.9(4.5,5.3)^{\mathrm{c}}$ & $0.320^{\mathrm{b}}$ \\
\hline
\end{tabular}

${ }^{a}$ Chi-square test. ${ }^{b}$ Kruskal-Wallis. ${ }^{c}$ Median (25 and 75 percentiles). ALT, alanine aminotransferase; AST, aspartate aminotransferase; TBIL, total bilirubin; GGT, $\gamma$-glutamyl transferase; GLU, glucose. 
A

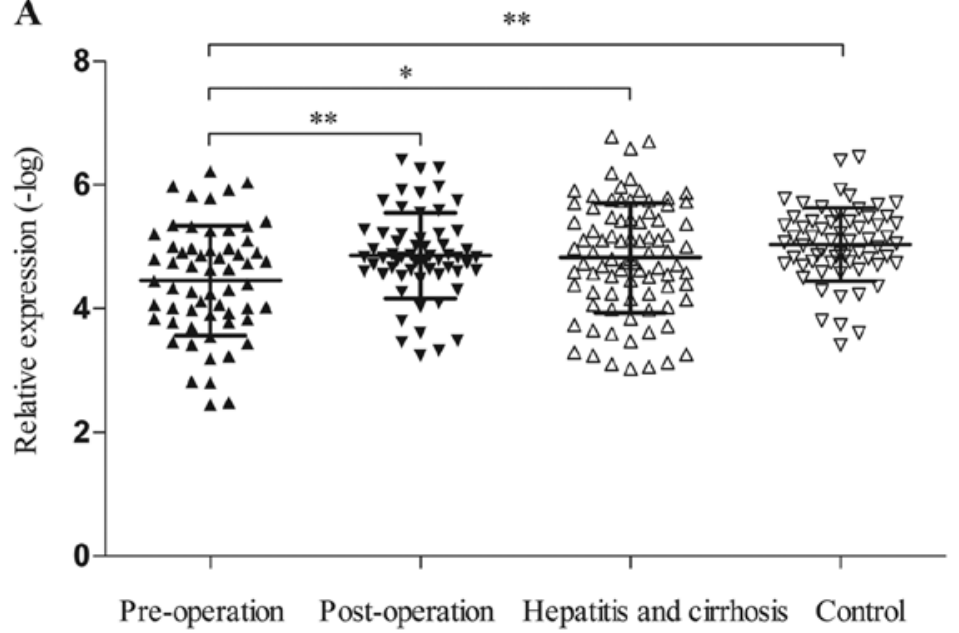

B

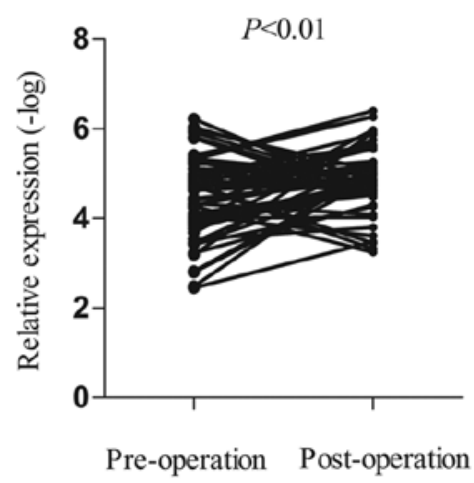

Figure 3. SPRY4-IT1 levels in plasma among subgroups. The relative SPRY4-IT1 expression was determined using RT-qPCR. (A) SPRY4-IT1 expression in pre-operation was higher than that in post-operation, hepatitis B and cirrhosis, and the control groups. No differences were observed among post-operation, hepatitis B and cirrhosis, and the control groups. (B) SPRY4-IT1 expression in pre-operation vs. post-operation. The data were analyzed using Student's t-test and one-way ANOVA. ${ }^{*} \mathrm{p}<0.05,{ }^{* *} \mathrm{p}<0.01$.

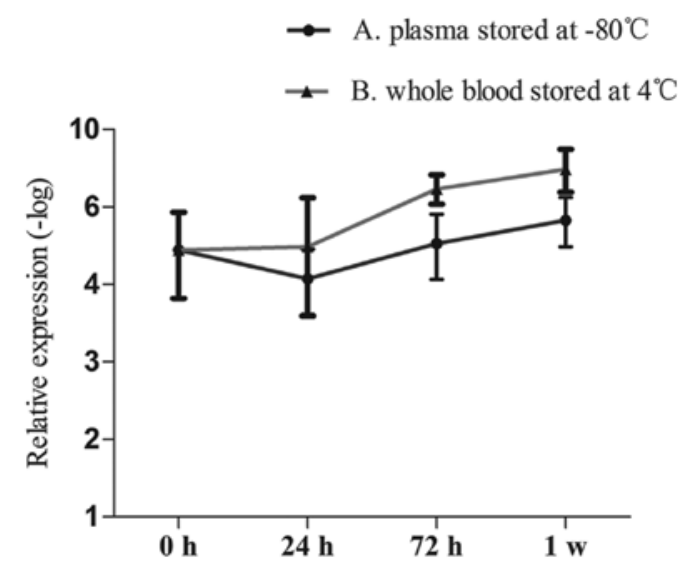

Figure 4. Stability detection of SPRY4-IT1 in human plasma. Human plasma was obtained from 5 healthy controls. A, Plasma was stored at $-80^{\circ} \mathrm{C}$ for $24 \mathrm{~h}, 72 \mathrm{~h}$, and 1 week. B, Whole blood was incubated at $4^{\circ} \mathrm{C}$ for 24 and $72 \mathrm{~h}$, and 1 week. All data were analyzed using Student's t-test. No significant difference was observed in each group.

the present study, and the levels of SPRY4-IT1 were decreased in 40 of $60 \mathrm{HCC}(66.7 \%)$ patients (Fig. 3B). However, upon comparison of the levels in the other three subgroups (postoperation, hepatitis B and cirrhosis, the controls), no marked differences were found.

Stability detection of SPRY4-IT1 in human plasma. The present study amplified SPRY4-IT1 in the plasma of HCC patients for the first time. Then, we detected the stability of this lncRNA. We collected plasma from 5 healthy individuals (4 men and 1 women) and stored the samples at $-80^{\circ} \mathrm{C}$ for 0 , 24 and $72 \mathrm{~h}$ and 1 week. Meanwhile, we obtained whole blood from these individuals, and stored the samples at $4^{\circ} \mathrm{C}$. We then separated the plasma at 0,24 and $72 \mathrm{~h}$ and 1 week. The expression of SPRY4-IT1 in the plasma was assessed by RT-qPCR. The results showed that the entire process had minimal effects on the levels of SPRY4-IT1 (Fig. 4).
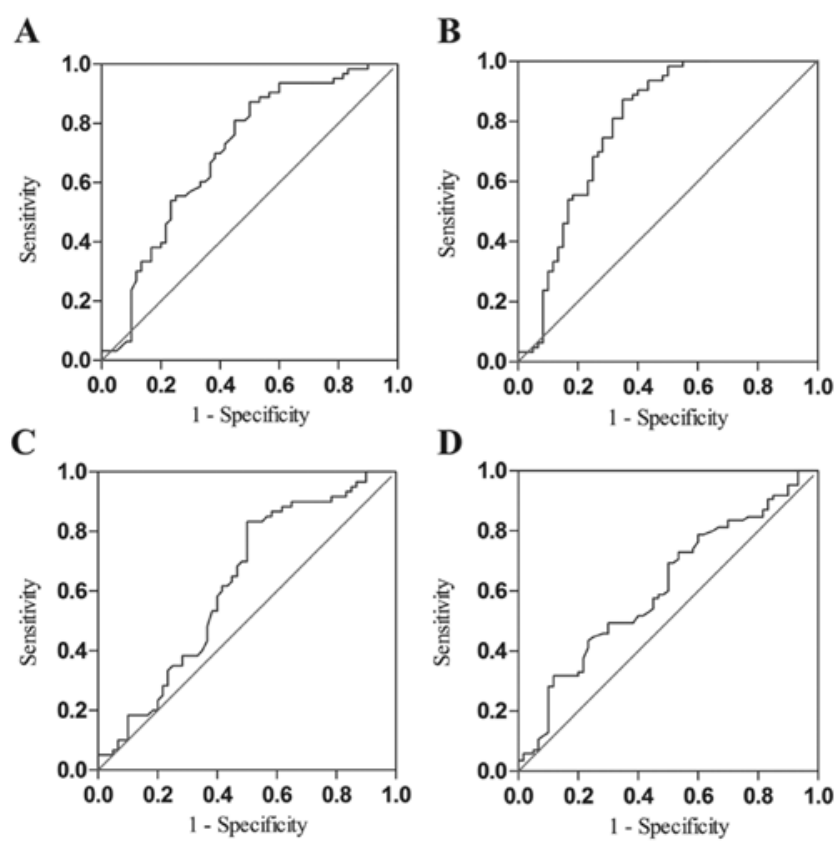

D

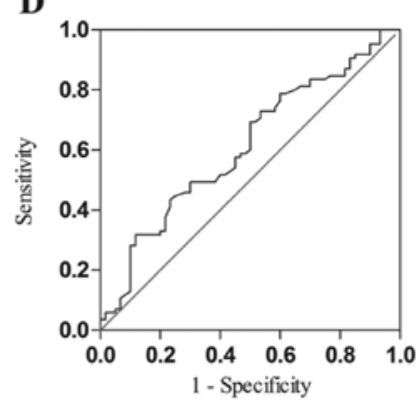

Figure 5. Receiver operating characteristic (ROC) curves. The ROC curves of the expression of SPRY4-IT1 for (A and B) pre-operation vs. controls, (C) pre-operation vs. post-operation and (D) pre-operation vs. hepatitis B and cirrhosis.

Diagnostic value analysis. To estimate the diagnostic value of SPRY4-IT1 in plasma, ROC was constructed using 3 models: pre-operation vs. the controls, and pre-operation vs. postoperation, and pre-operation vs. hepatitis B and cirrhosis. The area under the ROC (AUCROC) indicated that SPRY4-IT1 had adequate diagnostic value for differentiating $\mathrm{HCC}$ patients from the controls (Fig. 5A). Combination of SPRY4-IT1 and AFP (the cut-off value of AFP was at $200 \mathrm{ng} / \mathrm{ml}$ ) possessed a moderate ability for discrimination between HCC patients and controls; the area was equal to 0.80 (Fig. 5B). However, compared with the group of pre-operation vs. the controls, the 
Table IV. Comparisons of the AUC of the expression of SPRY4-IT1 in the subgroups.

\begin{tabular}{lccccc}
\hline Group & AUC & $95 \%$ CI & P-value & Se (\%) & Sp (\%) \\
\hline Pre vs. C & 0.702 & $0.609-0.796$ & $<0.001$ & 87.3 & 50.0 \\
Pre vs. C & 0.800 & $0.706-0.874$ & $<0.001$ & 87.3 & 65.0 \\
Pre vs. Post & 0.624 & $0.523-0.726$ & 0.019 & 83.3 & 49.0 \\
Pre vs. HC & 0.611 & $0.518-0.703$ & 0.024 & 43.5 & 86.7 \\
\hline
\end{tabular}

Pre, pre-operation; C, control; Post, post-operation; HC, hepatitis B and cirrhosis. AUC, area under the curve; Se, sensitivity; Sp, specificity; SPRY4-IT1, SPRY4 intronic transcript 1. ${ }^{\mathrm{a} C o m b i n a t i o n}$ of SPRY4-IT1 and AFP differentiated HCC patients from the controls.

diagnostic value of SPRY4-IT1 in the other two groups was not obvious (Fig. 5C and D and Table IV).

\section{Discussion}

For decades, much research has investigated potential biomarkers for hepatocellular carcinoma (HCC) (25). The prognosis of HCC remains quite poor, since most patients are diagnosed at an advanced stage, when treatments are less effective (26). Clinically, the most frequently used factor for the diagnosis of HCC is AFP, but the sensitivity is low (27). Using CT and MRI to diagnose the early stage of HCC, the sensitivity (55-91\%) and specificity (77-96\%) are higher (28). However, due to the different ability among doctors to identify the lesion, the accuracy is different. Recently, IncRNAs have been found to play an important role in the occurrence, invasion and metastasis of cancer (29). Only a few diverse hypothetical mechanisms have been presented to explain how lncRNAs exert their effects. These include interfering in the expression of the adjacent encoding protein gene (30); participating in transcription, chromatin-modifying and DNA methyltransferases to specific genomic (31); binding with functional protein (32); as precursors of miRNAs and affecting target genes of miRNAs $(33,34)$; regulating signaling pathway via combining with chromosome $(35,36)$. Bussemakers et al $(37)$ demonstrated that IncRNA PCA3 is a prostate cancer-specific gene. In addition, HULC has been detected in the plasma of HCC patients with high expression (5). Thus, IncRNAs may be considered as novel diagnostic targets for HCC.

In the present study, for the first time, we investigated the clinical value of SPRY4-IT1 in HCC patients. We found that SPRY4-IT1 was upregulated in HCC tissues and cell lines to a greater extent than levels in corresponding noncancerous tissues and normal human hepatocyte cell line L-02. Meanwhile, our data showed that SPRY4-IT1 expression was related to differentiation, tumor size and TNM stage. Kumarswamy et al (38) elaborated that circulating lncRNAs were from the tissues. Therefore, we also detected the expression of SPRY4-IT1 in plasma. The results showed that the levels of SPRY4-IT1 in HCC were much higher than levels in the controls, post-operation and hepatitis B and cirrhosis tissues. According to the present study, the expression of SPRY4-IT1 in plasma could be used to evaluate the effect after surgery in HCC. Due to a sharp decline in post-operative patients after 2 weeks, we supposed that the removal of tumor tissues did effect the contents of circulating IncRNAs. In 2014,
Liu et al (39) found that plasma lncRNA FER1L4 levels underwent a sharp decline in GC patients 2 weeks after surgery $(\mathrm{p}=0.028)$. Therefore, we hypothesized that SPRY4-IT1 played a role in the prognostic evaluation after surgery in the plasma of HCC patients. The occurrence of HCC involves a multifactor, multi-step and complex process. This concept was validated by the different expression levels of SPRY4-IT1 in the pre-operation group vs. the hepatitis B and cirrhosis group. However, the exact explanation needs further research.

Due to the existence of RNases, circulating lncRNAs are thought to be unstable (40). In the present study, we detected the expression of SPRY4-IT1 in plasma stored at 4 and $-80^{\circ} \mathrm{C}$ to assess the stability of SPRY4-IT1 in human plasma. No significant difference was observed in the process. Hu et al (41) also demonstrated the same result using another method. We confirmed that circulating IncRNAs were markedly stable.

For the first time, we detected the expression of SPRY4-IT1 in plasma to analysis the diagnostic value. The area under the AUC ROC showed that SPRY4-IT1 had a better diagnostic value to differentiate HCC patients from the control, but the diagnostic value of SPRY4-IT1 in the other two groups was not obvious. Further analysis showed that the combination of SPRY4-IT1 and AFP achieved a better diagnostic accuracy. Thus, SPRY4-IT1 may represent a promising target for HCC diagnosis. However, one limitation of the study was that the sample size was small, thus the present findings should be validated in trials with more cases.

Xie et al (42) indicated that SPRY4-IT1 led to gastric cancer cell metastasis partly via regulating epithelial-mesenchymal transition (EMT) and DNA methylation may be a key factor in controlling SPRY4-IT1 expression. Khaitan et al (43) found that SPRY4-IT1 could connect with multiple molecules in the mitogen-activated protein kinase (MAPK) signaling pathway promoting reduced apoptosis, induced proliferation and enhanced metastasis. In HCC, a number of studies reveal that EMT and the MAPK signaling pathway play important roles, thus SPRY4-IT1 may have an effect on the development of HCC $(44,45)$. Lee et al $(46)$ demonstrated that in prostate cancer, siRNA knockdown of SPRY4-IT1 in PC3 cells inhibited cell proliferation and invasion and increased cell apoptosis. These studies indicated that SPRY4-IT1 played an important role in tumorigenesis. Unfortunately, the exact function of SPRY4-IT1 in HCC is still unknown.

In conclusion, the present study provides insights into the expression levels of SPRY4-IT1 in HCC patients for the first time. We demonstrated that the expression of SPRY4-IT1 
was significantly higher in HCC than that in corresponding non-cancerous tissues and was correlated to differentiation, tumor size and TNM stage. In vitro, our results also showed that SPRY4-IT1 was upregulated in HCC cell lines to a greater extent than that in a normal human hepatocyte cell line. We then detected the levels in HCC plasma, and found that SPRY4-IT1 expression was upregulated in the HCC group, and SPRY4-IT1 exhibited good diagnostic value. These findings suggest for the first time that the expression of SPRY4-IT1 could be used as a novel diagnostic marker for HCC.

\section{Acknowledgements}

The present study was supported by the National Basic Research Program of China (973 Program) (2012CB720605).

\section{References}

1. Au JS and Frenette CT: Management of hepatocellular carcinoma: Current status and future directions. Gut Liver 9: 437-448, 2015.

2. Guo S, Chen W, Luo Y, Ren F, Zhong T, Rong M, Dang Y, Feng Z and Chen G: Clinical implication of long non-coding RNA NEAT1 expression in hepatocellular carcinoma patients. Int J Clin Exp Pathol 8: 5395-5402, 2015.

3. Waghray A, Murali AR and Menon KN: Hepatocellular carcinoma: From diagnosis to treatment. World J Hepatol 7: 1020-1029, 2015.

4. Chen KW, Ou TM, Hsu CW, Horng CT, Lee CC, Tsai YY, Tsai CC, Liou YS, Yang CC, Hsueh CW, et al: Current systemic treatment of hepatocellular carcinoma: A review of the literature. World J Hepatol 7: 1412-1420, 2015.

5. Xie H, Ma H and Zhou D: Plasma HULC as a promising novel biomarker for the detection of hepatocellular carcinoma. Biomed Res Int 2013: 136106, 2013.

6. Xu WH, Zhang JB, Dang Z, Li X, Zhou T, Liu J, Wang DS, Song WJ and Dou KF: Long non-coding RNA URHC regulates cell proliferation and apoptosis via ZAK through the ERK/MAPK signaling pathway in hepatocellular carcinoma. Int J Biol Sci 10: 664-676, 2014

7. Ilikhan SU, Bilici M, Sahin H, Akca AS, Can M, Oz II, Guven B, Buyukuysal MC and Ustundag Y: Assessment of the correlation between serum prolidase and alpha-fetoprotein levels in patients with hepatocellular carcinoma. World J Gastroenterol 21: 6999-7007, 2015.

8. Quagliata L, Matter MS, Piscuoglio S, Arabi L, Ruiz C, Procino A, Kovac M, Moretti F, Makowska Z, Boldanova T, et al: Long noncoding RNA HOTTIP/HOXA13 expression is associated with disease progression and predicts outcome in hepatocellular carcinoma patients. Hepatology 59: 911-923, 2014

9. Zhang G, Ha SA, Kim HK, Yoo J, Kim S, Lee YS, Hur SY, Kim YW, Kim TE, Park YG, et al: Combined analysis of AFP and HCCR-1 as an useful serological marker for small hepatocellular carcinoma: A prospective cohort study. Dis Markers 32 265-271, 2012

10. Fang TT, Sun XJ, Chen J, Zhao Y, Sun RX, Ren N and Liu BB: Long non-coding RNAs are differentially expressed in hepatocellular carcinoma cell lines with differing metastatic potential. Asian Pac J Cancer Prev 15: 10513-10524, 2014.

11. Brockdorff N, Ashworth A, Kay GF, McCabe VM, Norris DP Cooper PJ, Swift S and Rastan S: The product of the mouse Xist gene is a $15 \mathrm{~kb}$ inactive $\mathrm{X}$-specific transcript containing no conserved ORF and located in the nucleus. Cell 71: 515-526, 1992.

12. Khachane AN and Harrison PM: Mining mammalian transcript data for functional long non-coding RNAs. PLoS One 5: e10316, 2010 .

13. Wang TH, Lin YS, Chen Y, Yeh CT, Huang YL, Hsieh TH, Shieh TM, Hsueh C and Chen TC: Long non-coding RNA AOC4P suppresses hepatocellular carcinoma metastasis by enhancing vimentin degradation and inhibiting epithelial-mesenchymal transition. Oncotarget 6: 23342-23357, 2015.

14. Huang JL, Zheng L, Hu YW and Wang Q: Characteristics of long non-coding RNA and its relation to hepatocellular carcinoma. Carcinogenesis 35: 507-514, 2014.
15. Takahashi K, Yan IK, Kogure T, Haga H and Patel T: Extracellular vesicle-mediated transfer of long non-coding RNA ROR modulates chemosensitivity in human hepatocellular cancer. FEBS Open Bio 4: 458-467, 2014

16. Wang F, Ying HQ, He BS, Pan YQ, Deng QW, Sun HL, Chen J, Liu X and Wang SK: Upregulated IncRNA-UCA1 contributes to progression of hepatocellular carcinoma through inhibition of miR-216b and activation of FGFR1/ERK signaling pathway. Oncotarget 6: 7899-7917, 2015.

17. Liu H, Lv Z and Guo E: Knockdown of long noncoding RNA SPRY4-IT1 suppresses glioma cell proliferation, metastasis and epithelial-mesenchymal transition. Int J Clin Exp Pathol 8: 9140-9146, 2015.

18. Mouraviev V, Lee B, Patel V, Albala D, Johansen TE, Partin A, Ross A and Perera RJ: Clinical prospects of long noncoding RNAs as novel biomarkers and therapeutic targets in prostate cancer. Prostate Cancer Prostatic Dis 19: 14-20, 2016.

19. Shi Y, Li J, Liu Y, Ding J, Fan Y, Tian Y, Wang L, Lian Y, Wang K and Shu Y: The long noncoding RNA SPRY4-IT1 increases the proliferation of human breast cancer cells by upregulating ZNF703 expression. Mol Cancer 14: 51, 2015.

20. Sun M, Liu XH, Lu KH, Nie FQ, Xia R, Kong R, Yang JS, Xu TP Liu YW,Zou YF, et al: EZH2-mediated epigenetic suppression of long noncoding RNA SPRY4-IT1 promotes NSCLC cell proliferation and metastasis by affecting the epithelial-mesenchymal transition. Cell Death Dis 5: e1298, 2014.

21. Xie HW, Wu QQ, Zhu B, Chen FJ, Ji L, Li SQ, Wang CM, Tong YS, Tuo L, Wu M, et al: Long noncoding RNA SPRY4-IT1 is upregulated in esophageal squamous cell carcinoma and associated with poor prognosis. Tumour Biol 35: 7743-7754, 2014.

22. Mazar J, Zhao W, Khalil AM, Lee B, Shelley J, Govindarajan SS, Yamamoto F, Ratnam M, Aftab MN, Collins S, et al: The functional characterization of long noncoding RNA SPRY4-IT1 in human melanoma cells. Oncotarget 5: 8959-8969, 2014.

23. Peng $\mathrm{W}, \mathrm{Wu} \mathrm{G}$, Fan $\mathrm{H}, \mathrm{Wu} \mathrm{J}$ and Feng J: Long noncoding RNA SPRY4-IT1 predicts poor patient prognosis and promotes tumorigenesis in gastric cancer. Tumour Biol 36: 6751-6758, 2015

24. Zhang HM, Yang FQ, Yan Y, Che JP and Zheng JH: High expression of long non-coding RNA SPRY4-IT1 predicts poor prognosis of clear cell renal cell carcinoma. Int J Clin Exp Pathol 7: 5801-5809, 2014.

25. Tang J, Jiang R, Deng L, Zhang X, Wang K and Sun B: Circulation long non-coding RNAs act as biomarkers for predicting tumorigenesis and metastasis in hepatocellular carcinoma. Oncotarget 6: 4505-4515, 2015.

26. Tu ZQ, Li RJ, Mei JZ and Li XH: Down-regulation of long non-coding RNA GAS5 is associated with the prognosis of hepatocellular carcinoma. Int J Clin Exp Pathol 7: 4303-4309, 2014

27. Yamashita T, Kitao A, Matsui O, Hayashi T, Nio K, Kondo M, Ohno N, Miyati T, Okada H, Yamashita T, et al: Gd-EOB-DTPA-enhanced magnetic resonance imaging and alpha-fetoprotein predict prognosis of early-stage hepatocellular carcinoma. Hepatology 60: 1674-1685, 2014.

28. Jain D: Tissue diagnosis of hepatocellular carcinoma. J Clin Exp Hepatol 4 (Suppl 3): S67-S73, 2014.

29. Huang M, Chen WM, Qi FZ, Xia R, Sun M, Xu TP, Yin L, Zhang EB, De W and Shu YQ: Long non-coding RNA ANRIL is up-regulated in hepatocellular carcinoma and promotes cell apoptosis by epigenetically silencing of KLF2. J Hematol Oncol 8: 57, 2015.

30. Khalil AM and Rinn JL: RNA-protein interactions in human health and disease. Semin Cell Dev Biol 22: 359-365, 2011.

31. Khalil AM, Guttman M, Huarte M, Garber M, Raj A, Rivea Morales D, Thomas K, Presser A, Bernstein BE, van Oudenaarden A, et al: Many human large intergenic noncoding RNAs associate with chromatin-modifying complexes and affect gene expression. Proc Natl Acad Sci USA 106: $11667-11672,2009$

32. Huarte M, Guttman M, Feldser D, Garber M, Koziol MJ, Kenzelmann-Broz D, Khalil AM,Zuk O, Amit I, Rabani M, et al: A large intergenic noncoding RNA induced by p53 mediates global gene repression in the p53 response. Cell 142: 409-419, 2010 .

33. Cesana M, Cacchiarelli D, Legnini I, Santini T, Sthandier O, Chinappi M, Tramontano A and Bozzoni I: A long noncoding RNA controls muscle differentiation by functioning as a competing endogenous RNA. Cell 147: 358-369, 2011.

34. Zhao Q, Li T, Qi J, Liu J and Qin C: The miR-545/374a cluster encoded in the Ftx lncRNA is overexpressed in HBV-related hepatocellular carcinoma and promotes tumorigenesis and tumor progression. PLoS One 9: e109782, 2014. 
35. Nagano $T$ and Fraser P: No-nonsense functions for long noncoding RNAs. Cell 145: 178-181, 2011.

36. Chen LL and Carmichael GG: Decoding the function of nuclear long non-coding RNAs. Curr Opin Cell Biol 22: 357-364, 2010.

37. Bussemakers MJ, van Bokhoven A, Verhaegh GW, Smit FP, Karthaus HF, Schalken JA, Debruyne FM, Ru N and Isaacs WB: DD3: A new prostate-specific gene, highly overexpressed in prostate cancer. Cancer Res 59: 5975-5979, 1999.

38. Kumarswamy R, Bauters C, Volkmann I, Maury F, Fetisch J, Holzmann A, Lemesle G, de Groote P, Pinet F and Thum T: Circulating long noncoding RNA, LIPCAR, predicts survival in patients with heart failure. Circ Res 114: 1569-1575, 2014.

39. Liu Z, Shao Y, Tan L, Shi H, Chen S and Guo J: Clinical significance of the low expression of FER1L4 in gastric cancer patients. Tumour Biol 35: 9613-9617, 2014.

40. Tsui NB, Ng EK and Lo YM: Stability of endogenous and added RNA in blood specimens, serum, and plasma. Clin Chem 48 $1647-1653,2002$.

41. Hu X, Bao J, Wang Z, Zhang Z, Gu P, Tao F, Cui D and Jiang W: The plasma lncRNA acting as fingerprint in non-small-cell lung cancer. Tumour Biol: Oct 9, 2015 (Epub ahead of print).
42. Xie M, Nie FQ, Sun M, Xia R, Liu YW, Zhou P, De W and Liu XH: Decreased long noncoding RNA SPRY4-IT1 contributing to gastric cancer cell metastasis partly via affecting epithelial-mesenchymal transition. J Transl Med 13: 250, 2015.

43. Khaitan D, Dinger ME, Mazar J, Crawford J, Smith MA, Mattick JS and Perera RJ: The melanoma-upregulated long noncoding RNA SPRY4-IT1 modulates apoptosis and invasion. Cancer Res 71: 3852-3862, 2011.

44. Zhang L, Yang F, Yuan JH, Yuan SX, Zhou WP, Huo XS, Xu D, Bi HS, Wang F and Sun SH: Epigenetic activation of the MiR-200 family contributes to H19-mediated metastasis suppression in hepatocellular carcinoma. Carcinogenesis 34: 577-586, 2013.

45. Ma L, Ji L, Yu Y and Wang J: Novel molecular targets for diagnosis and treatment of hepatocellular carcinoma. Discov Med 19: 7-14, 2015.

46. Lee B, Mazar J, Aftab MN, Qi F, Shelley J,Li JL, Govindarajan S, Valerio F, Rivera I, Thurn T, et al: Long noncoding RNAs as putative biomarkers for prostate cancer detection. J Mol Diagn 16: 615-626, 2014. 